\title{
Pre-harvest deterioration of Sour sop (Annona muricata) at Ibadan Southwestern Nigeria and its effect on nutrient composition
}

\author{
N. A. Amusa*, O. A. Ashaye, M. O. Oladapo and O.O. Kafaru \\ Institute of Agricultural Research and Training Obafemi, Awolowo University Moor Plantation PMB 5029 Ibadan, Nigeria \\ Accepted 19 December 2002
}

\begin{abstract}
The etiology of pre-harvest deterioration of Soursop (Annona muricata) fruit in Ibadan, southwestern Nigeria and the effects on its nutrient composition was investigated. Four fungal pathogens including Botryodiplodia theobromae, Fusarium sp., Rhizopus stolonifer and Aspergillus niger were found associated with the pre-harvest deteriorating soursop . B. theobromae was the most prevalent and the most pathogenic inducing rot of $75 \mathrm{~mm}$ in diameter within four days of inoculation. There was a remarkable reduction in carbohydrate and protein contents of the fungal infected fruits while all other nutrients and mineral assayed were higher in the infected fruits than the non-infected ones.
\end{abstract}

Key words: Annona muricata, fungal pathogens, pre-harvest deterioration.

\section{INTRODUCTION}

Soursop (Annona miricata) belongs to the family Annonaceae, and it is wide spread in the tropics and frost-free subtropics of the world (Samson, 1980). The soursop plant is cultivated mainly in home gardens. The tree yields up to 10 tons/ha and each fruit weighs 0.5 to 2 $\mathrm{kg}$ (National Academy Of Science, 1978).

The fruit makes an excellent drink or ice cream after straining. Its white edible pulp contains $80 \%$ water, $1 \%$ protein, $18 \%$ carbohydrate and fair amount of vitamins $B_{1}, B_{2}$, and $C$ (Rice et al., 1991). The seeds are flat, hard and contain oil that can be used for paint or insecticide.

Visits made to some soursop home gardens in Ibadan metropolis revealed that several fruits were found deteriorating on the tree. Hence the aim of the study was to investigate the etiology of pre-harvest deterioration of soursop fruits in Ibadan, Southwestern Nigeria, and the effects on its nutrient composition.

\section{MATERIALS AND METHODS}

Fifty soursop trees from the University of Ibadan (UI) Botanical Garden, National Institute of Horticultural Research (NIHORT), Forestry Research Institute of Nigeria (FRIN), Cocoa Research Institute of Nigeria (CRIN) and a private farm (10 per location) all located in Ibadan, South western Nigeria were used for the research experiment in the year 1999 and 2000 . Ibadan $\left(7^{\circ} 20^{\prime} \mathrm{N}\right.$, $3^{\circ} 50^{\prime} \mathrm{E}$ : $200 \mathrm{~mm}$ above sea level) is in a transition zone between the humid forest and the wet, sub-humid savannah agro- ecological zone of Nigeria. An average of about $1200-\mathrm{mm}$ rainfall is received per annum in Ibadan, with $90 \%$ of the rainfalls during the rainy

*Corresponding author; e-mail: drart@infoweb.abs.net season, April to October. Mean daily temperature varies between $24^{\circ} \mathrm{C}$ (night) and $34^{\circ} \mathrm{C}$ (day) is fairly uniform throughout the year. Infected soursop fruits were collected from above mentioned locations within Ibadan metropolis, kept in sampling bags and taken to the pathology laboratory of the Institute of Agricultural Research and Training, Obafemi Awolowo University (IAR and T/OAU) Moor Plantation, Ibadan, Nigeria.

The infected portions were excised and cut into $2 \mathrm{~mm}^{2}$ pieces, surface sterilized with $1 \% \mathrm{NaOCl}$ and rinsed in 4 successive changes of sterile distilled water. The excised infected portions were then plated on to potato dextrose agar (PDA) in petri dishes and incubated for six days under alternating 12-hour light and dark periods at $26^{\circ} \mathrm{C}$. Fungal cultures that emerged were examined under a stereo binocular microscope. The identity of these fungi was certified using cultural, morphological, pathogenicity tests as well as comparing them with confirmed representatives of the different species (Barnett and Hunter, 1972; Booth, 1977; Purseglove, 1968).

Pathogenicity Test: Freshly harvested clean none-infected (matured) Soursop fruits were surface sterilized by swabbing with $70 \%$ alcohol and bored into with a sterile cork-borer (4-mm). Another sterile cork- borer ( $4 \mathrm{~mm}$ in diameter) was used to cut pellets of agar containing 3-day-old cultures of fungal mycelia of the isolates, which were used to inoculate the hole created by scooping out soursop tissue. The scooped out tissues were replaced to cover the borehole. The inoculated fruits were then enclosed in polythene bags containing moist cotton wool to maintain high relative humidity and incubated at $25^{\circ} \mathrm{C}$ in Gallenkamp incubators for 7 days. Six fruits were inoculated per isolate, replicated 4 times while the control fruits were inoculated with PDA agar discs. The extent of rot was determined by measuring the size of infection $(\mathrm{mm})$. Wet mounts of hyphal/asexual structures obtained from these infected materials were stained with lactophenol in cotton blue and viewed under the compound microscope for the presence of the pathogen and identified as describe above.

The incidence of occurrence of the pathogens was determined by examining three infected fruits per plant and 15 soursop plants per location were used as the experimental site. 
Nutrient Composition: Three infected and non-infected fruits per tree, and 5 trees per location were used for the analysis. Samples were excised from the harvested fruits, weighed, cut into pieces and dried in a hot air oven at $60^{\circ} \mathrm{C}$ for 3 days. The dried pieces of the fruits were ground into powder and analyzed for moisture, carbohydrates, ash, crude fibre, crude protein, and crude fat according to AOAC (1984) procedure. Mineral analysis was carried out according to standard AACC (1983) method.

\section{RESULTS AND DISCUSSION}

Of the 50 soursop trees examined, $65 \%$ had more than $35 \%$ pre-harvest deteriorating fruits, $20 \%$ had between 15 to $30 \%$ fruits infection, while $15 \%$ were free of infection. Four fungal isolates were found associated with the pre-harvest deteriorating soursop. These include Botryodiplodia theobromae, Fusarium sp., Rhizopus stolonifer and Aspergillus niger. B. theobromae was the most prevalent of the pathogens, followed by Fusarium sp while $R$. stolonifer was found associated with only $7 \%$ of the fruits (Table 1).

Table 1. Incidence of occurrence and pathogenicity of fungi found associated with soursop.

\begin{tabular}{lcc}
\hline Fungal Isolates & $\begin{array}{l}\text { Rate }(\%) \text { of } \\
\text { occurrence }\end{array}$ & $\begin{array}{c}\text { Diameter of } \\
\text { infection }(\mathrm{mm})\end{array}$ \\
\hline B. theobromae & 100 & 75 \\
Fusarium sp. & 34 & 18 \\
R. stolonifer & 8 & 35 \\
A. niger & 22 & 22 \\
\hline
\end{tabular}

Fungal pathogens are known to be responsible for the post-harvest deteriorating of many tropical fruits. $B$. theobromae has been reported to be one of the most important fruit rot pathogen in southwestern Nigeria
(Adisa and Fajola,1982). R. stolonifer and A. niger are air borne fungi (Raper and Fennell, 1968), and probably secondary invaders as well as opportunistic pathogens. Olunloyo (1986) has previously reported the involvement of Penicillium citrinum, A. niger, Fusarium sp. and Rhizopus sp. in the deterioration of another tropical fruit, cashew (Anacardium occidentale). The pre-harvest rot of immature fruits is associated with Lasiodiplodia theobromae (Olunloyo, 1979).

The fungal pathogens responsible for the preharvesting deterioration of soursop might have probably resided in dead stems and then dispersed by rain splash into the growing fruits to initiate infection spore. It is also possible that insect vectors disperse the pathogens.

The pathogenicity test revealed that all the isolates were pathogenic and when re-isolated from the infected materials, the fungi were identical to the initial isolates. $B$. theobromae induces rot of $75 \mathrm{~mm}$ diameter within 4 days of inoculation, followed by $R$. stolonifer which also induced mean rot of $35 \mathrm{~mm}$ within the same period (Table1). It has been reported that $B$. theobromae infection of cashew fruit reduces its yield per hectare by $38.72 \%$ (Olunloyo, 1979).

Nutrient analysis revealed that the freshly harvested non-infected soursop fruits have between 14.88-14.91\% carbohydrates and $78.49-78.68 \%$ moisture content in all 5 locations in Ibadan (Table 1). About 39\% reduction in the carbohydrate contents was observed in the infected freshly harvested fruits. This is most probably due to the degradative activities of the pathogens leads to reduction of the quality of the fruit. The nutrient analysis of the freshly harvested fruits revealed that total crude proteins accounted for $1.20-1.24 \%$; ash, $0.89-0.90 \%$; dry matter, $19.15-19.35 \%$; K, $1.39-1.41 \%$; and $\mathrm{Na}, 0.63-0.65 \%$ all 5 locations (Table 2). Comparable values have also been documented by Rice et al. (1991). The infected fruits had about 20 and $11 \%$ loss in crude protein and dry matter, respectively. However, the ash and moisture contents of

Table 2. Nutrient content ${ }^{\alpha}$ of fungal- infected and non-infected soursop fruits in Ibadan, Southwestern Nigeria.

\begin{tabular}{|c|c|c|c|c|c|c|c|c|c|c|}
\hline & \multicolumn{2}{|c|}{ University of Ibadan } & \multicolumn{2}{|c|}{ FRIN } & \multicolumn{2}{|c|}{ CRIN } & \multicolumn{2}{|c|}{ NIHORT } & \multicolumn{2}{|c|}{ Private farm } \\
\hline $\begin{array}{c}\text { Analyzed } \\
\text { nutrients } \\
(\%)\end{array}$ & $\begin{array}{c}\text { Non- } \\
\text { infected } \\
\text { fruit }\end{array}$ & $\begin{array}{c}\text { Infected } \\
\text { fruit }\end{array}$ & $\begin{array}{c}\text { Non- } \\
\text { infected } \\
\text { fruit }\end{array}$ & $\begin{array}{c}\text { Infected } \\
\text { fruit }\end{array}$ & $\begin{array}{c}\text { Non- } \\
\text { infected } \\
\text { fruit }\end{array}$ & $\begin{array}{c}\text { Infected } \\
\text { fruit }\end{array}$ & $\begin{array}{c}\text { Non- } \\
\text { infected } \\
\text { fruit }\end{array}$ & $\begin{array}{c}\text { Infected } \\
\text { fruit }\end{array}$ & $\begin{array}{c}\text { Non- } \\
\text { infected } \\
\text { fruit }\end{array}$ & $\begin{array}{l}\text { Infecte } \\
d \text { fruit }\end{array}$ \\
\hline C.P. & 1.21 & 1.00 & 1.20 & 1.03 & 1.19 & 0.98 & 1.24 & 1.18 & 1.21 & 1.04 \\
\hline Ash & 0.90 & 1.12 & 0.91 & 1.11 & 0.89 & 1.13 & 0.90 & 1.13 & 0.90 & 1.12 \\
\hline MC. & 78.65 & 81.50 & 78.95 & 81.51 & 78.68 & 81.49 & 78.66 & 81.50 & 78.65 & 81.48 \\
\hline $\mathrm{K}^{*}$ & 1.41 & 2.51 & 1.40 & 2.51 & 1.41 & 2.50 & 1.39 & 2.50 & 1.41 & 2.51 \\
\hline $\mathrm{Ca}^{*}$ & 0.65 & 2.51 & 0.63 & 2.51 & 0.65 & 2.51 & 0.64 & 2.51 & 0.66 & 2.51 \\
\hline $\mathrm{Na}^{*}$ & 0.13 & 0.21 & 0.13 & 0.21 & 0.12 & 0.20 & 0.14 & 0.19 & 0.13 & 0.21 \\
\hline $\mathrm{P}^{*}$ & 2.07 & 2.80 & 2.07 & 2.79 & 2.06 & 2.78 & 2.07 & 2.79 & 2.09 & 2.78 \\
\hline
\end{tabular}

${ }^{\alpha}$ Proximate composition (\% dry matter) ${ }^{*}$ Analyzed minerals (\% dry matter)

$\mathrm{CHO}$ : carbohydrate; CP-crude protein; MC- moisture content; DM-dry matter; K-potassium; Ca calcium; P- Phosphorus. 
the infected fruits were higher than that of the noninfected ones. Similar increase in mineral contents in the infected fruits was also observed (Table 2). It could be deduced that deterioration of the fruit by pathogens might have led to release of minerals from organic or biochemical complexes leading to increase in ash content.

In conclusion, fungal infection leads to a reduction in carbohydrate and protein contents of the soursop pulp which might have a remarkable effect on the value of the fruit, especially in the food industry. We therefore recommended timely spraying of the fruits with fungicides to reduce the damaging activities of the fungal pathogen and contamination with mycotoxins and other related fungal metabolites that might be harzadous to human health. Since some of these pathogens gain access via wounds created by insect pests, there is also the need for further investigations of the pests causing injuries on soursop fruits, with the aims of reducing their activities.

\section{REFERENCES}

AACC (1983). Approved methods of the AACC, $3^{\text {rd }}$ edition, American Association of Cereal Chemist, St. Paul, Minnesota.

Adisa VA, Fajola AO (1982). Post harvest fruit rots of three species of citrus in southern Nigeria. Indian Phytopathol. 35:595-603.
AOAC (1984). Association of Official Analytical Chemist, Official Method of Analysis, $14^{\text {th }}$ edition, Washington, DC.

Barnett HL, Hunter BB (1972). Illustrated Genera of Imperfect Fungi. Mineapolis: Burgress Publishing Co.

Booth CH (1977). Fusarium: Laboratory Guide to the Identification of major species, Kew, Surrey, UK: Commonwealth Mycological Institute.

National Academy Of Science (1978). Under exploited tropical plant with promising economic value, Wash. DC.

Olunloyo OA (1979). The role of fruit flies in rot disease of cashew apples in the plantation. Annual Rept. Cocoa Research Institute of Nigeria. Ibadan, pp. 101-105.

Olunloyo OA (1986). Initiation and field prevalence of fungal rot of Pseudo-apples of cashew in the plantation. Paper delivered at the $22^{\text {nd }}$ Annual Conference of Agricultural Society of Nigeria, Zaria, September, pp. 1-4.

Purseglove JW (1968). Tropical crops. Longman. Singapore.

Raper KB, Fennell DF (1965). The Genus Aspergillus. Baltimore: Williams and Wilkins.

Rice RP, Rice LW, Tindal HD (1991). Fruit and Vegetable Production in Warm Climates. Macmillian Education Ltd, pp363.

Samson JA (1980). Tropical Fruits, $2^{\text {nd }}$ edition (Tropical Agriculture Series) Longman Singapore publishers (PLC) 336 p. 